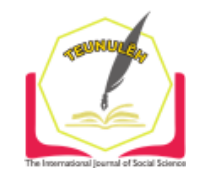

Jurnal Ilmiah Teunuleh

The International Journal of Social Sciences

Vol. 1, Issue. 2, Dec 2020

E-ISSN: 2746-4393

\title{
STUDENTS' CRITICAL THINKING ABILITY, CREATIVE AND LEARNING STYLE IN INDONESIAN LEARNING FOR GRADE IV SD NEGERI 112238 SEPADAN JAYA
}

\author{
Ariati $^{1}$ \\ Isda Pramuniati ${ }^{2}$ \\ Evi Eviyanti ${ }^{3}$ \\ ${ }^{123}$ State University of Medan, Indonesia
}

\begin{abstract}
This study aims to describe students 'critical thinking ability, students' creativity skills, and the learning style of grade 4 students at SDN 112238 Sepadan Jaya in Indonesian language lessons. This research uses qualitative descriptive method with a population of all grade 4 students at SDN 112238 Sepadan Jaya in the 2020/2021 school year of 21 students. The variables in this study were students' critical thinking ability, creativity, and learning style which included visual, auditorial and kinesthetic. Data collection techniques using questionnaires and analysis techniques used are descriptive statistics. The results showed that the average grade 4 at SDN 112238 Sepadan Jaya in the 2020/2021 school year in Bahasa Indonesia has the majority ability in the highly critical thinking category, at around $47.6 \%$. Ability majority in the creative category, in percentage about $66.67 \%$. The majority of learning styles are Kinesthetic, students have a tendency to one of the visual, auditory or kinesthetic learning styles, with the average student having a tendency on visual learning style 33.33\%, auditory learning style 14.28\%, and kinesthetic learning style $52.38 \%$.
\end{abstract}

Keywords: Critical Thinking, Creativity, Visual Learning Style, Auditory, Kinesthetic.

\section{A. Introduction}

The critical thinking skills of Indonesian students are still low. It is known that based on the results of the Program for International Student Assessment (PISA, 2014), Indonesia's scientific literacy score is 382 with a ranking of 64 out of 65 participating countries (PISA, 2014). The questions tested in PISA consisted of 6 levels (the lowest level 1 and the highest level 6 ) and the questions tested were contextual questions whose 
problems were taken from the real world. Students in Indonesia are only able to answer routine questions at level 1 and level 2 (Kertayasa, 2015). This shows that the ability of Indonesian students to answer questions that refer to the ability to think critically, logically, and solve problems is still very low.

Thinking is an activity that humans always do, even when they are asleep. For the brain, thinking and solving problems is the most important job, even with unlimited abilities. Thinking is one of the most important forces and a characteristic that distinguishes humans from animals. According to Sardiman, thinking is a mental activity to be able to formulate understanding, synthesize, and draw conclusions (Sardiman, 1996, p. 45). Purwanto argues that thinking is an activity of the human person that results in directed discovery towards a goal. Humans think to find the understanding/understanding they want (Purwanto, 2007). Santrock also expressed his opinion that thinking is manipulating or managing and transforming information in memory. Thinking is often done to form concepts, reason and think critically, make decisions, think creatively, and solve problems. (Santrock, 2011)

If thinking is part of an activity that the brain always does to organize information to achieve a goal, then critical thinking is part of thinking activities that the brain also does. According to Santrock, critical thinking is reflective and productive thinking, and involves evaluating evidence (Santrock, 2011). Jensen argues that critical thinking means an effective and reliable mental process, used in the pursuit of relevant and correct knowledge about the world (Jensen, 2011). According to Wijaya, he also expressed his ideas about critical thinking skills, namely the activity of analyzing ideas or ideas in a more specific direction, distinguishing them sharply, selecting, identifying, studying and developing them in a more perfect direction. Creative thinking skills can be developed through education (Wijaya, 2010). This statement is in accordance with the formulation in Law number 20 concerning the National Education System in 2003 which states that national education aims to develop the potential of students to become human beings who believe and fear God Almighty, have noble character, and have noble personalities; knowledgeable, competent, critical, creative, and innovative; healthy, independent, and confident; and tolerant, socially sensitive, democratic, and responsible, towards the surrounding environment. Such ability will be possible if the education graduate has creativity.

According to Akhadiah, creativity is essentially a manifestation of the ability to think creatively. By realizing their creative thinking skills, students can actualize 
Students' Critical Thinking Ability, Creative and Learning Style in Indonesia Learning...

themselves (Akhadiah, Arsyad, \& Ridwan, 1993). This self-actualization is a basic need at the highest level in human life (Munandar, 1999). In addition, the ability to think creatively is the key to success in solving problems, because it is creativity that bridges the stages of managing cognition to the stage of execution so that someone has convincing achievements or results. (Sunito, 2013). Meanwhile, in the current era of globalization, someone's ability to think creatively is increasingly needed which is expected to be able to make a meaningful contribution to science, technology, arts and to the welfare of the nation in general. (Munandar, 1999). Those are some reasons that the ability to think creatively is very important to be stimulated, nurtured and developed from an early age.

Evans stated that, the ability to think creatively is a mental ability that a person uses to build new ideas or ideas. Every student has this ability, but the level varies from one student to another (Siswono, 2008). Thus, a valid criterion or standard for creative thinking is needed. Siswono explained that the criteria for the level of creative thinking are useful as a comparison or reference to find out where student weaknesses are and how to overcome those weaknesses (Siswono, 2007). In addition, the level of students 'creative thinking abilities can be used as an indication of the quality of students' abilities in creative thinking and their development during the learning process. Munandar argued that creativity is a multidimensional construct that can be viewed from the cognitive, affective, and psychomotor dimensions. (Munandar, 1977). Therefore, the ability to think creatively can be measured through several approaches. In addition, there are various types of tools used to measure, namely direct measurement, indirect measurement, measurement with the elements that mark these characteristics, measurement of personality traits that are closely related to these sections, and several types of non-test measurements. According to Sapriya, the purpose of critical thinking is to test an opinion or idea, including making considerations or thoughts based on the opinions put forward. (Sapriya, 2011).

Following are the characteristics of critical thinking according to Wijaya (Wijaya, 2010)able to identify in detail, detect problems, distinguish ideas that are relevant from irrelevant ones, distinguish facts from diction or opinion, identify differences or information gaps; distinguish logical and illogical arguments; develop criteria or data assessment standards, like to collect data for factual evidence, be able to distinguish between constructive and destructive criticism, identify multiple perspective views related to data, test assumptions carefully, examine ideas that conflict with events in the 
environment, identify attributes- attributes of humans, places and objects, such as in nature, form, form, etc., list all possible consequences or alternative solutions to problems, ideas, and situations.

The critical thinking skills of Indonesian students are still low. It is known that based on the results of the Program for International Student Assessment (PISA, 2014), Indonesia's scientific literacy score is 382 with a ranking of 64 out of 65 participating countries (PISA, 2014). The questions tested in PISA consisted of 6 levels (the lowest level 1 and the highest level 6) and the questions tested were contextual questions whose problems were taken from the real world. Students in Indonesia are only able to answer routine questions at level 1 and level 2 (Kertayasa, 2015). This shows that the ability of Indonesian students to answer questions that refer to the ability to think critically, logically, and solve problems is still very low.

Based on the facts about these educational problems, refreshing is for the teacher so that it can improve students' critical thinking skills which involve students directly in the fact finding process of the material information being taught. To overcome this problem, one of the learning models that can be used is a learning model that invites students to think critically and creatively. Learning develops active student learning methods by discovering by yourself, investigating by yourself, then the results obtained will be loyal and long-lasting in memory, students will not easily forget. By learning discovery, children can also learn to think analytically and solve problems themselves. This habit will be transferred to social life. Therefore students are expected to be able to analyze and write down the relationship of concepts used in solving problems and have active questioning of the teacher, and have active group discussions to increase student creativity so that students have more creativity in the learning process and have a learning style that has extraordinary abilities. Ordinary and able to take advantage of circumstances. Based on the background of this problem, researchers are interested in conducting research with the title "Analysis of Critical Thinking Ability, Creative and Student Learning Styles in Class IV Indonesian Language Learning SD Negeri 112238 Sepadan Jaya."

\section{B. Method}

This type of research is descriptive qualitative with the research subjects are students of class IVA SD Negeri 112238 Sepadan Jaya, amounting to 21 people. Data collection techniques using observation, tests, documentation and interviews. The 
Students' Critical Thinking Ability, Creative and Learning Style in Indonesia Learning...

observation technique is carried out to obtain data related to the implementation of Indonesian language learning both inside and outside the classroom. In addition, this technique is also used to determine the level of critical thinking skills, creative thinking and learning styles of students in learning Indonesian for grade IVa SD Negeri 112238 Sepadan Jaya. The test data collection technique is used to measure the skills, knowledge, attitudes, intelligence abilities or talents possessed by individuals or groups. The documentation technique is used to obtain data about activities related to the circumstances and operations of the research object. Interviews (interviews) are conducted directly between the person in charge of collecting data and the person who is the data source or research object.

The research instrument used was a questionnaire, in the form of a closed research questionnaire, with the aim of providing subjective assessments for respondents (Musfiqon, 2012). Then this questionnaire is measured using a Likert scale (Sarwono, 2006), with the alternative answers SS (Very Often), S (Often), K (Sometimes), $\mathrm{J}$ (Rarely), and $\mathrm{T}$ (Never). The score for the positive statements, the highest score for each statement number is 4 and the lowest score for each statement is 0 . Then the questionnaire was tested using the product moment correlation equation proposed by Pearson and reliability with the Apha-Cronbach formula. (Arikunto, 2010) with the help of the SPSS 25 program. The test was carried out in two forms (Padmono, 1999), namely the oral test and the written test. Written test, if the test delivers questions and statements in writing and the test answers questions or statements in writing.

The data obtained through a questionnaire were analyzed descriptively to determine the percentage of answers to the statement. This questionnaire uses a formula (Sarwono, 2006):

$$
\mathrm{P}=\frac{\text { Frekuensi masing-masing individu }}{\text { jumlah frekuensi }} \times 100 \%
$$

Information: $\mathrm{P}=$ Percentage of individual answers

\section{Finding and Discussion}

1. Questionnaire results for the ability to think critically, creatively, and student learning styles

The average grade IVA SDN 112238 Sepadan Jaya academic year 2020/2021 has the ability to think critically in Indonesian language learning, based on a questionnaire of critical thinking skills from 12 statements given to 21 students, it can be seen from the percentage acquisition as follows: 
Ariati, Isda Pramuniati, Evi Eviyanti

Table 1.1. Grouping the Results of Students' Critical Thinking Analysis

\begin{tabular}{|l|l|c|c|c|c|}
\hline \multicolumn{2}{|c|}{ Critical Thinking Category } & $\begin{array}{c}\text { Frequenc } \\
\text { y }\end{array}$ & Percent & $\begin{array}{c}\text { Valid } \\
\text { Percent }\end{array}$ & $\begin{array}{c}\text { Cumulative } \\
\text { Percent }\end{array}$ \\
\hline \multirow{4}{*}{ Valid } & $13-22=$ Less Critical & 1 & 4.8 & 4.8 & 4.8 \\
\cline { 2 - 6 } & $23-32=$ Critical Enough & 2 & 9.5 & 9.5 & 14.3 \\
\cline { 2 - 6 } & $33-42=$ Critical & 8 & 38.1 & 38.1 & 52.4 \\
\cline { 2 - 6 } & $>43-48=$ Very Critical & 10 & 47.6 & 47.6 & 100 \\
\cline { 2 - 6 } & Total & 21 & 100.0 & 100.0 & \\
\hline
\end{tabular}

Source: results of the SPSS data analysis

From the results of the table data analysis shows that the average level of critical thinking skills of students in the very critical category is around $47.6 \%$ or as many as 10 people from the entire population, the critical thinking category is 8 people or around $38.1 \%$, the category is quite critical as many as 2 people or about 9,5\% and less critical category as much as 1 person or $4.8 \%$. From the questionnaire analysis, it can be concluded that the average level of critical thinking skills of grade IVA students of SDN 112238 Sepadan Jaya in Indonesian language learning is in the very critical category.

While in the average grade IVA SDN 112238 Sepadan Jaya students who have the ability to be creative in learning Indonesian from the provision of questionnaires, the percentage results of the questionnaire analysis are obtained as follows:

Table 1.2. Student Creativity Analysis Results Grouping

\begin{tabular}{|c|c|c|c|c|}
\hline $\begin{array}{c}\text { Student Creativity } \\
\text { Category }\end{array}$ & Frequency & Percent & Valid Percent & Cumulative Percent \\
\hline $11-20=$ Creative Enough & 7 & 33.3 & 33.3 & 33.3 \\
\hline $21-30=$ Creative & 14 & 66.7 & 66.7 & 100.0 \\
\hline Total & 21 & 100.0 & 100.0 & \\
\hline
\end{tabular}

Source: results of the SPSS data analysis

The results of the table analysis show students with a creative verbal creativity level of about $66.7 \%$ or as many as 14 students. While students with a creative level of creativity were around $33.33 \%$ or as many as 7 students from the entire population. From this analysis it can be concluded that the results of this study indicate the average level of creativity ability of grade IVA SDN 112238 Sepadan Jaya students in Indonesian language learning is included in the creative category. 
Students' Critical Thinking Ability, Creative and Learning Style in Indonesia Learning...

The results of a questionnaire analysis of grade IVA students at SDN 112238 Sepadan Jaya for the 2020/2021 academic year who have a kinesthetic learning style in Indonesian language learning, can be seen in the table to get the following percentage:

Table 1.3. Grouping the Results of Student Learning Style Analysis

\begin{tabular}{|c|c|c|c|r|}
\hline $\begin{array}{c}\text { Category Student } \\
\text { Learning Style }\end{array}$ & Frequency & Percent & $\begin{array}{c}\text { Valid } \\
\text { Percent }\end{array}$ & Cumulative Percent \\
\hline Visual & 7 & 33.3 & 33.3 & 33.3 \\
\hline Auditory & 3 & 14.3 & 14.3 & 47.6 \\
\hline Kinesthetic & 11 & 52.4 & 52.4 & 100 \\
\hline Total & 21 & 100.0 & 100.0 & \\
\hline
\end{tabular}

Source: results of the SPSS data analysis

The results of the table analysis show students with a kinesthetic learning style of around $52.38 \%$ or as many as 11 students from the entire population. Students with visual learning styles were around $33.33 \%$ or as many as 7 students, and students with auditory learning styles were around $14.28 \%$ or as many as 3 students. From this analysis it can be concluded that the average learning style of fourth grade students at SDN 112238 Sepadan Jaya in Indonesian language learning is dominated by kinesthetic learning styles.

\section{Discussion of Research Results}

Based on the research results, the Indonesian language learning process with the 2013 curriculum can improve the ability of grade IV SDN 112238 Sepadan Jaya students to think critically. Display in graph 2.1. The following describes the ability of students to think critically by $47.6 \%$ or as many as 10 people, the critical thinking category was $38.1 \%$ or as many as 8 people, the critical enough category was $9.5 \%$ or as many as 2 people and the less critical category was $4.8 \%$ or as much as 1 person. So from the results of the research analysis it can be concluded that the average grade IV SDN 112238 student has the ability to think critically after the Indonesian learning process with the 2013 curriculum. 


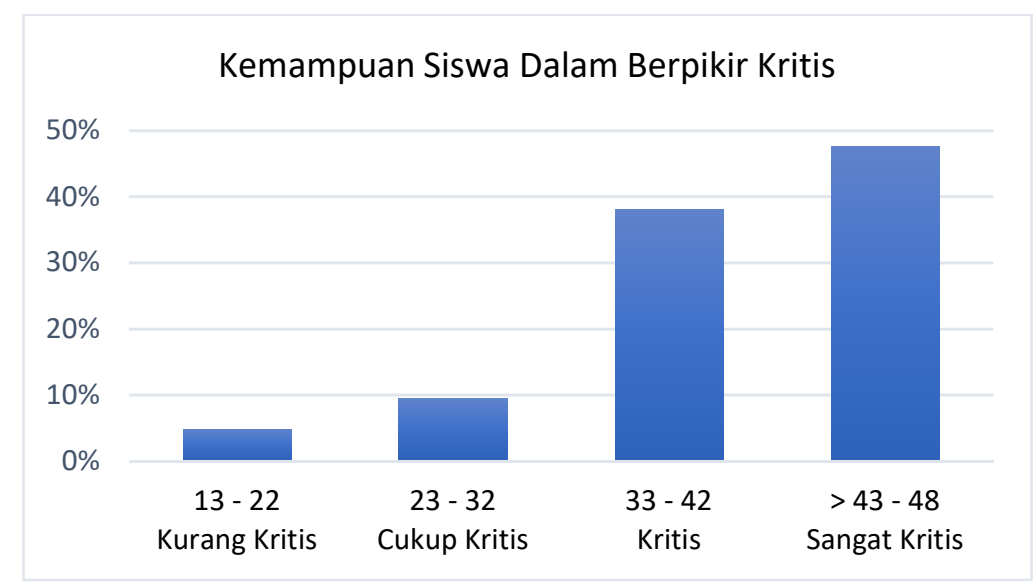

Graph 2.1. Graph of Class IV Student Ability Grouping in Critical Thinking

Critical thinking is a complex thinking process that is thinking logically and aims to make sound decisions, through a systematic scientific process which includes analyzing, synthesizing, recognizing problems and solutions, concluding and evaluating. (Prameswari, 2018). In some developed countries, critical thinking is one of the goals of education because critical thinking is a higher-order thinking skill and is useful in moral, social, mental, cognitive development and science (Hashemi, et.al, 2010). Simply put, someone who thinks critically can answer problems in a good, precise, and clear way. Some of the characteristics of critical thinking include the ability to make conclusions and solutions that are accurate, clear, and relevant to existing conditions. The second characteristic is open thinking systematically and has logical assumptions, implications, and consequences. The third characteristic is communicating effectively in solving a complex problem (Hidayat, 2012).

Critical thinking skills should be developed from the elementary school level through the 2013 Curriculum learning process, including Indonesian language learning so that students are trained to think critically (Prameswari et al., 2018). The 2013 curriculum requires students to be active in the Indonesian language learning process. Students are not only invited to read and observe, but are also involved in the process of practicing and discussing. This is in line with the opinionBonnie and Potts (2003) who explain that the characteristics of learning critical thinking include: (1) Increasing interaction between students, (2) By asking open-ended questions, (3) Providing adequate time for students to provide reflection on questions that are proposed or given problems, and (4) Teaching for transfer (Teaching to be able to use the abilities that have just been acquired in other situations and on the students' own experiences that 
Students' Critical Thinking Ability, Creative and Learning Style in Indonesia Learning...

students have). So that the activity that must be developed in students' critical thinking skills is to answer innovative questions: Is there another way? (What's another way?), What if...? (What if...?), which one is wrong? (What's wrong?), and what will be done? (What would you do?) (Krulik \& Rudnick, 1999). Therefore,

This is in line with research result (Rakhmat, 2017)which states that the increase in mathematical critical thinking skills of students of Social Studies at SMAN Bandung with the learning method of Creative Problem Solving (CPS) assisted by Desmos is better than the increase in the ability to think critically in mathematics of superior and ASOR students who receive conventional learning. Likewise with the results of Damanik and Bukit's research (Damanik, 2013)In the Journal of Physics Education, it is revealed that the critical thinking skills of students who use the Inquiry Training (IT) learning model are better than the critical thinking skills of students who use the Direct Instruction (DI) learning model. Inquiry Training (IT) Learning Model has several advantages, namely helping students to develop critical thinking skills, problem-solving abilities, and in general to develop intellectual skills. The characteristic of the IT model is that the problem determination is formulated in a question so that students must develop critical thinking skills to solve problems by researching, studying and looking for problem solutions.

Based on the description above, it can be concluded that teachers who apply the Indonesian language learning process with the 2013 curriculum with varied and innovative learning models / methods / strategies / approaches can improve students' ability to think critically and even critically.

Creative thinking is an expression (expression) of the uniqueness of an individual in interaction with his environment. From unique personal expressions it can be expected that new ideas and innovative products will emerge and the presence of characteristics such as: being able to direct oneself to a certain object, being able to detail an idea, being able to analyze ideas and the quality of personal work, being able to create a new ideas in problem solving (Munandar, 1999). Creativity is divided into two, namely: verbal creativity and figural creativity. In this study, the observed creativity was verbal creativity. Verbal creativity is the ability to make new combinations based on data, information or elements found from possible answers to a problem and expressed verbally. 
Ariati, Isda Pramuniati, Evi Eviyanti

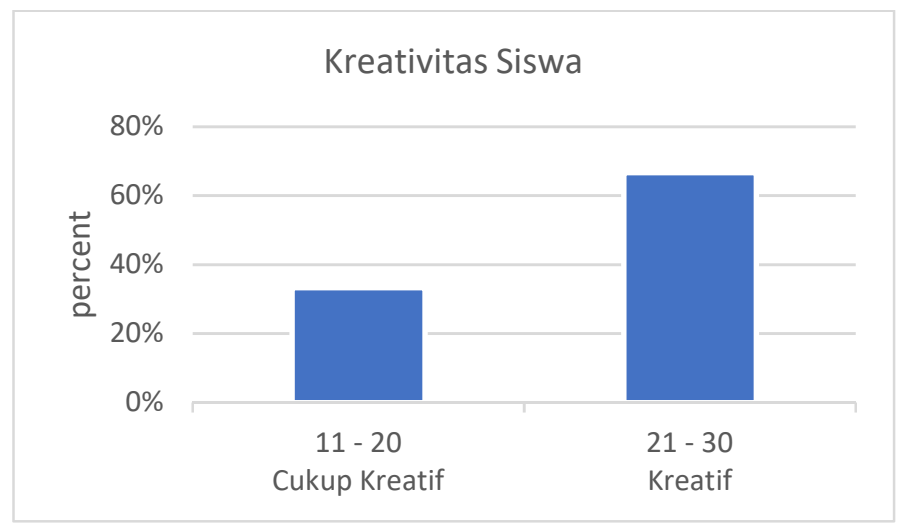

Graph 2.2. Graph of Class IV Students' Ability Grouping in Creativity

Based on graph 2.2 showing the verbal creativity ability of fourth grade students of SDN 112238 Sepadan Jaya consists of two categories, namely: the level of verbal creativity with a creative category of around $66.7 \%$ or as many as 14 students, and students with a fairly creative level of creativity around $33.33 \%$ or as much as 7 students from the entire population. In graph 2.2 it is clear that the average grade IV student of SDN 112238 Sepadan Jaya has good verbal creativity skills, so it can be concluded that the learning process of Indonesian with the 2013 curriculum has succeeded in increasing the creativity abilities of grade IV students of SDN 112238 Sepadan Jaya. According to Rogers in (Munandar, 2009), the development of creativity is influenced by two factors, namely internal factors (student personal) and external factors (such as parents, family environment, teachers, school facilities, learning methods / models, curriculum). The implementation of the 2013 Curriculum in schools does not only require students to have creative abilities, but also requires creative teachers. Creative teachers are the key to the success of the Indonesian language learning process in schools because creative teachers are able to design learning models that stimulate students to be active and think creatively in the process of Indonesian language learning activities, such as completing texts, conducting interviews, discussing.

This is in line with Malahayati's research results (Malahayati, 2017) in the Constructivism Journal that Student Worksheets (LKS) based on Creative Problem Solving (CPS) on the material of biodiversity increase critical thinking skills and student learning outcomes by 0.54 and 0.10 respectively compared to the use of textbook media. The CPS learning model is a model in accordance with the objectives of the current 2013 curriculum where the CPS learning model involves a lot of creative activities in problem solving, such as document research, observation of the surrounding environment, 
Students' Critical Thinking Ability, Creative and Learning Style in Indonesia Learning...

activities related to science, and creative writing, so that students can improve. ability to think creatively by developing ideas and thoughts. Likewise, Soeyono's research results (Soeyono, 2014)in the Journal of Mathematics Education concluded that class $X$ mathematics teaching materials using an open-ended approach showed an increase in the average ability of students to think creatively. The open-ended approach is an approach that is in accordance with the 2013 Curriculum which aims to increase students' creative activity and mathematical thinking skills in solving problems simultaneously. By providing contextual problems at the beginning of learning, forcing students to use the experience and knowledge they have learned to solve these problems. The answers that students may respond to will help students and teachers hone their ability to compare, look for similarities or differences, analyze, and make conclusions from experiences they have just had in class.

Based on the description above, it can be concluded that teachers who apply the Indonesian language learning process with the 2013 curriculum with various models / methods / strategies / approaches can motivate students to increase their creative abilities.

Grade IV students of SDN 112238 Sepadan Jaya for the 2020/2021 academic year are a collection of students who have different cultural, gender, academic and experience characteristics that affect students in their learning styles. Every student has a diverse learning style, including grade IV SDN 112238 Sepadan Jaya. In Figure 2.3 the fourth grade students of SDN 112238 consist of three groups, namely: visual, auditory, and kinesthetic learning styles. Kinesthetic learning styles are children's learning styles that are easier to capture the material conveyed by the teacher through body movements. While the visual learning style is a learning style that is easier to accept material through the sense of sight/eyes, and auditory learning style is a learning style that is easier to accept material through the sense of hearing/ears (Arylien LB et al., 2014). Based on the data above, students with kinesthetic learning styles are around $52.38 \%$ or as many as 11 students from the entire population, students with visual learning styles around $33.33 \%$ or as many as 7 students, and students with auditory learning styles around $14.28 \%$ or as many as 3 students. 
Ariati, Isda Pramuniati, Evi Eviyanti

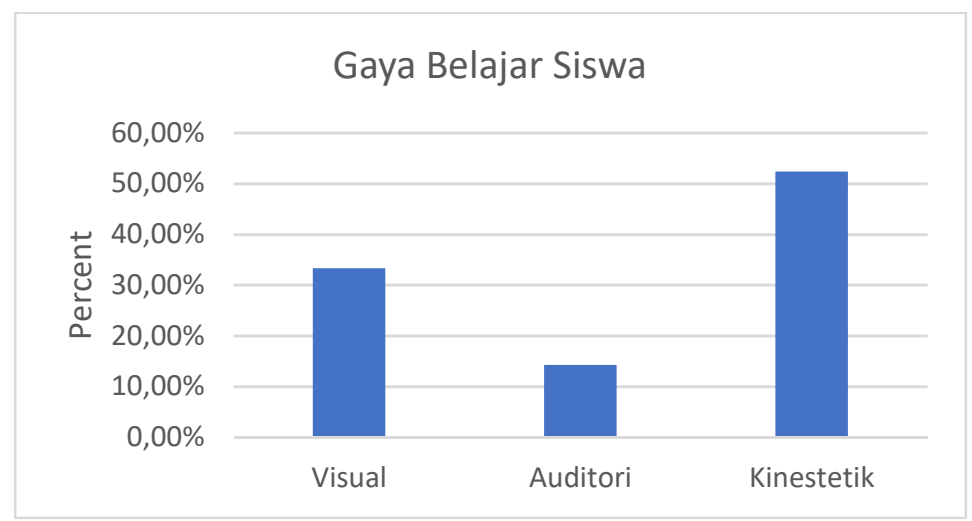

Graph 2.3 Bar Graph of Class IV Student Learning Styles Grouping SDN 112238

Although the results of this study concluded that the average learning style of fourth grade students at SDN 112238 Sepadan Jaya in Indonesian language learning is dominated by kinesthetic learning styles. However, a creative teacher must be able to package learning that involves the three student learning styles, namely visual, auditory, and kinesthetic learning styles. This is in accordance with Kadir \& Ashrohan's statement (Kadir \& Ashrohah, 2015)that integrative thematic learning based on the 2013 curriculum is a learning approach that integrates several subject competencies into a theme, in addition to integrative thematic learning competencies it also combines learning styles for learning activities because each student's learning style is different from one another. It is intended that all students easily understand the learning process effectively even though it has different characteristics, but thematic learning requires all students to be actively involved in learning activities.

The integrative thematic Indonesian learning that has been carried out in this study is able to accommodate all learning styles, namely: visual, auditory, and kinesthetic learning styles. The implementation of Indonesian language lessons combined with science, social studies, PPKN, and mathematics lessons in several themes, invites students to read, observe, conduct interviews, discuss, practice, in groups. During the observation, all students are actively involved in the learning process. This is in accordance with Prastiwi's opinion (Prastiwi, 2016)which states that learning that includes all learning styles will be more meaningful for students and the material is easily understood by students because in this process discrimination in student learning styles is lost.

Based on the description above, it can be concluded that the average learning style of fourth grade students of SDN 112238 Sepadan Jaya in Indonesian language learning 
Students' Critical Thinking Ability, Creative and Learning Style in Indonesia Learning...

with thematic integrative is dominated by kinesthetic learning styles. Although the average student learning style is a kinesthetic learning style, the teacher must be able to package learning that involves the three student learning styles, namely visual, auditory, and kinesthetic learning styles so that all students can understand the learning conveyed by the teacher.

From the results of the analysis of the three variables in this study, conclusions can be drawn in Table 2.1 below:

Table 2.1. Analysis of Critical Thinking, Creativity and Learning Style of Class IV Students of SDN 112238

\begin{tabular}{|c|c|c|c|c|}
\hline No. & Respondents & Think Critical & Creativity & Learning Style Trends \\
\hline 14 & R14 & Very Critical & Creative & Kinesthetic \\
\hline 16 & R16 & Very Critical & Creative & Kinesthetic \\
\hline 10 & R10 & Very Critical & Creative & Kinesthetic \\
\hline 18 & R18 & Very Critical & Creative & Kinesthetic \\
\hline 9 & R9 & Very Critical & Creative & Kinesthetic \\
\hline 3 & R3 & Very Critical & Creative & Kinesthetic \\
\hline 8 & R8 & Very Critical & Creative & Kinesthetic \\
\hline 2 & R2 & Very Critical & Creative & Kinesthetic \\
\hline 7 & R7 & Very Critical & Creative & Kinesthetic \\
\hline 5 & R5 & Critical & Creative & Kinesthetic \\
\hline 17 & R17 & Critical Enough & Pretty Creative & Visual \\
\hline 13 & R13 & Very Critical & Pretty Creative & Visual \\
\hline 15 & R15 & Critical & Pretty Creative & Visual \\
\hline 11 & R11 & Critical & Pretty Creative & Visual \\
\hline 12 & R12 & Critical & Pretty Creative & Visual \\
\hline 6 & R6 & Critical & Creative & Visual \\
\hline 19 & R19 & Critical & Creative & Visual \\
\hline 4 & R4 & Less Critical & Pretty Creative & Visual \\
\hline 20 & R20 & Critical & Creative & Auditory \\
\hline 21 & R21 & Critical & Creative & Auditory \\
\hline 1 & R1 & Critical Enough & Pretty Creative & Auditory \\
\hline
\end{tabular}


Based on the table above, the sorting is done by sorting the level of critical thinking of students then analyzed by student creativity and learning styles. The results obtained are that there are 9 students (42.86\%) who have a kinesthetic learning style with critical thinking skills and a good level of creativity. As much as 1 student $(4.76 \%)$ has a kinesthetic learning style with good critical thinking skills and creativity levels.

Furthermore, in the visual learning style, there are 1 student $(4.27 \%)$ who has the ability to think critically with a good level of creativity, 2 students (14.29\%) with sufficiently good critical thinking and creativity skills, 3 students (14.76\%) who have the ability critical thinking with a fairly good level of creativity, 1 student (4.27\%) with sufficiently critical abilities and good enough creativity, and 1 student (4.27\%) who had sufficiently less critical and creative abilities. In the auditory learning style, there are 2 students (14.76\%) who have sufficient ability to think critically and creativity quite well, and 1 student (4.27\%) who are categorized as quite critical and quite creative.

From the analysis above, it can be concluded that the kinesthetic learning style is the best learning style because it is able to train students in critical thinking and develop verbal creativity. For this reason, teachers should not only teach by showing pictures and lectures, but even more so encourage children to do it themselves.

\section{Conclusion}

Based on the results of research and discussion, it can be concluded:

The process of learning Indonesian with the 2013 curriculum can improve the ability of grade IV students at SDN 112238 Sepadan Jaya for the 2020/2021 academic year to think critically and even critically. It can be seen that the average student thinks very critically by $47.6 \%$ or as many as 10 people. While the critical thinking category was $38.1 \%$ or as many as 8 people, the fairly critical category was $9.5 \%$ or 2 people and the less critical category was $4.8 \%$ or as many as 1 person.

The learning process of Indonesian with the 2013 curriculum can improve the verbal creativity skills of fourth grade students of SDN 112238 Sepadan Jaya for the $2020 / 2021$ academic year which can be seen from the average grade IV students of SDN 112238 Sepadan Jaya that the majority have good verbal creativity skills of $66.7 \%$ or as many as 14 students. While students with a creative level of creativity were around $33.33 \%$ or as many as 7 students from the entire population.

The fourth grade students of SDN 112238 Sepadan Jaya for the 2020/2021 academic year consist of three groups of learning styles, namely: visual, auditory, and 
Students' Critical Thinking Ability, Creative and Learning Style in Indonesia Learning...

kinesthetic learning styles. Students with visual learning styles are around $33.33 \%$ or as many as 7 students, students with auditory learning styles are around $14.28 \%$ or as many as 3 students, and students with kinesthetic learning styles are around $52.38 \%$ or as many as 11 students from the entire population. From the results of this study, the average learning style of fourth grade students at SDN 112238 Sepadan Jaya in the academic year 2020/2021 in Indonesian language learning is dominated by kinesthetic learning styles. Kinesthetic learning style is the best learning style because it is able to train students in critical thinking and develop verbal creativity.

\section{Bibliography}

Akhadiah, S., Arsyad, M. G., \& Ridwan, S. H. (1993). Pembinaan Kemampuan Menulis Bahasa Indonesia. Jakarta: Erlangga.

Arikunto, S. (2010). Prosedur Penelitian Penelitian Suatu Pendekatan Praktik. Jakarta: Rineka Cipta.

Damanik, D. d. (2013). Analisis Kemampuan Berpikir Kritis dan Sikap Ilmiah Pada Pembelajaran Fisika Menggunakan Model Pembelajaran Inquiry Training (IT) Dan Direct Instruction (DI). Jurnal Pendidikan Fisika, 2(1), 16-24.

Hidayat, W. (2012). Meningkatkan Kemampuan Berpikir Kritis dan Kreatif Matematika Melalui Pembelajaran Kooperatif Think-Talk-Write Pada Siswa Kelas VII SMA Sunan Ampel Gresik Tahun Ajaran 2011/2012. Surabaya: IAIN Sunan Ampel Surabaya.

Jensen, E. (2011). Pemelajaran Berbasis-Otak. Paradigma Pengajaran Baru. Jakarta: PT Indeks.

Kadir, A., \& Ashrohah. (2015). Pembelajaran Tematik. Jakarta: Raja Grafindo.

Kertayasa. (2015, januari 12). Indonesia PISA Center. Retrieved from http://www.indonesiapisacenter.com:

http://www.indonesiapisacenter.com/2014/03/tentang-website.html

Malahayati. (2017). Pengaruh Lembar Kerja Siswa (LKS) Berbasis Creative Problem Solving (CPS) pada Materi Keanekaragaman Hayati untuk Meningkatkan Kemampuan Berpikir Kritis dan Hasil Belajar Siswa Kelas X SMAN 4 Blitar. Jurnal Konstruktivisme, 9(2), 147-158.

Munandar, S. C. (1977). Creativity and Education, Disertasi Doktor U.I. Jakarta: Universitas Indonesia.

Munandar, S. C. (1999). Kreatifitas dan Keberbakatan. Jakarta: Gramedia Pustaka Utama.

Munandar, S. C. (2009). Pengembangan Kreativitas Anak Berbakat. Jakarta: Rineka Cipta.

Musfiqon. (2012). Pengembangan Media Belajar Dan Sumber Belajar. Jakarta: Prestasi Pustakakarya. 
Prameswari, S. S. (2018). Inculcate Critical Thinking Skills in Primary Schools. National Seminar on Elementary Education (SNPD 2018). SHEs: Conference Series 1 , (pp. 742-750).

Prastiwi, M. (2016). Gaya Belajar Siswa dan Implementasinya dalam Pembelajaran Tematik Integratif. Jurnal, 1-12.

Purwanto. (2007). Psikologi Pendidikan Remaja. Bandung: Rosdakarya.

Rakhmat. (2017). Penggunaan Pembelajaran Creative Problem Solving Berbantuan Desmos dalam Upaya Meningkatkan Kemampuan BerpikirKritis dan Berpikir Kreatif serta Dampaknya terhadap Kecemasan Belajar Matematika Siswa. Bandung: Tesis program pascasarjana universitas pasundan.

Santrock. (2011). Perkembangan Anak (Vol. 7). (S. G. B., Trans.) Jakarta: Erlangga.

Sapriya. (2011). Pendidikan IPS Konsep dan Pembelajaran. Bandung: PT Remaja Rosdakarya.

Sardiman. (1996). Interaksi dan motivasi belajar mengajar. Jakarta: PT. Raja Grafindo Persada.

Sarwono. (2006). Metode Penelitian Kuantitatif dan Kualitatif. Yogyakarta: Graha Ilmu.

Siswono. (2007). Penjenjangan Kemampuan Berpikir Kreatif dan Identifikasi Tahap Berpikir Kreatif Siswa Dalam Memecahkan dan Mengajukan Masalah Matematika. Surabaya.

Siswono. (2008). Model Pembelajaran Matematika Berbasis Pengajuan Masalah dan Pemecahan Masalah Untuk Meningkatkan Kemampuan Berpikir Kreatif. Surabaya: Unesa University Press.

Soeyono. (2014). Pengembangan bahan ajar matematika dengan pendekatan openended untuk meningkatkan kemampuan berpikir kritis dan kreatif siswa SMA. PYTHAGORAS: Jurnal Pendidikan Matematika. Jurnal Pendidikan Matematika, 9(2), 205-218.

Sunito. (2013). Metaphorming Beberapa Strategi Berpikir Kreatif. Jakarta: Indeks.

Wijaya. ( 2010). Pendidikan Remidial. Bandung: Remaja Rosdakarya. 